\title{
Influence of Therapy on Some Important Final Products of Oxidation of Lipids, Proteins and Nucleic Acids in Patients with Parkinson's Diseases
}

\author{
Galina D. Nikolova*, Boncho G. Grigorov, Antoaneta M. Zheleva, Veselina G. Gadjeva \\ Department of Chemistry and Biochemistry, Medical Faculty, Trakia University, Stara Zagora, Bulgaria \\ Email: " gnikkolova@gmail.com
}

Received 16 April 2014; revised 27 May 2014; accepted 15 June 2014

Copyright (C) 2014 by authors and Scientific Research Publishing Inc.

This work is licensed under the Creative Commons Attribution International License (CC BY).

http://creativecommons.org/licenses/by/4.0/

(c) (i) Open Access

\begin{abstract}
The major clinical disturbances in Parkinson's disease (PD) are consequence of dopamine depletion in the neostriatum, due to degeneration of dopaminergic neurons. The aim of the present study was to determine whether oxidative stress (OS) occurs during the clinical course of Parkinson's disease and to evaluate the influence of therapy on the levels of some important final products of oxidation of lipids, proteins and nucleic acids in PD patients with drug therapy. For this purpose, we investigated the levels of malondialdehid (MDA), protein carbonyl content (PCC) and 8hydroxy-2'-deoxyguanosine quantity (8-OHdG) in PD patients with and without drug therapy. The observed changes in MDA levels, PCC and 8-OHdG quantity in blood of untreated PD patients, suggested impaired antioxidant status and presence of oxidative stress in Parkinson disease. After treatment with Madopar, the elevation in by-products significantly progresses. Our results demonstrate that administration of Madopar causes in greater degree oxidative stress than that induced by Parkinson disease, by itself.
\end{abstract}

\section{Keywords}

Free Radicals, Malondialdehyde, 8-Hydroxy-2'-Deoxyguanosine, Protein Carbonyl Content

\section{Introduction}

Parkinson's disease (PD) takes a leading place among contemporary frequent diseases of the central nervous system (CNS). This is a slow, progressive disease, characterized by loss of dopaminergic neurons in the Subs-

"Corresponding author.

How to cite this paper: Nikolova, G.D., Grigorov, B.G., Zheleva, A.M. and Gadjeva, V.G. (2014) Influence of Therapy on Some Important Final Products of Oxidation of Lipids, Proteins and Nucleic Acids in Patients with Parkinson's Diseases. Advances in Biological Chemistry, 4, 253-260. http://dx.doi.org/10.4236/abc.2014.44031 
tantia Nigra (SN) pars compacta [1]. To explain the neurodegenerative mechanisms that occur in PD, numerous hypotheses have been proposed and some of them show that oxidative stress plays a considerable role [2]-[5]. Imbalance between levels of reactive oxygen species (ROS) resulting in the body and the capacity of antioxidant defense mechanisms provokes oxidative stress (OS). In the course of PD, ROS activates processes causing damage to lipids, proteins and DNA [4].

The most commonly used drug in the PD treatment is levodopa (L-dopa). It is a precursor of dopamine and thus complete deficiency of dopamine in the CNS. After oral intake L-dopa undergoes metabolism, including oxidative dopamine metabolism, auto-oxidation and across the blood-brain barrier (BBB). Only less than 5\% of an oral dose of L-dopa is delivered to the brain. Remaining plasmatic levels of L-dopa undergoes peripheral oxidative metabolism and may generate ROS. Likely peripheral oxidative status in PD patients might be affected by L-dopa therapy [6] [7]. It is applied with Dopa-decarboxylase inhibitors, so it achieves decrease of peripheral conversion of Levodopa to Dopamine. The dopamine agonists are products that directly affect striatal dopamine receptors and apply for advanced PD in combination with L-dopa. In the CNS, L-dopa is quickly transformed in dopamine and both may be relevant in OS [8]. However, some studies showed that L-dopa treatment increased the protein carbonyl content (PCC) and quantity of 8-OHdG [9]-[11], on the other side some evidence suggests an antioxidant effect of L-dopa [12].

The present study was aimed to determine whether OS occurs during the clinical course of PD and to evaluate the influence of drug therapy with Madopar on the levels of some important final products of oxidation of lipids, proteins and nucleic acids, such as plasma concentrations of MDA, PCC and quantity of 8-OHdG.

\section{Material and Methods}

\subsection{Chemicals}

The Thiobarbituric acid and Protein Carbonyl and Oxidative DNA Damage ELISA kits were purchased from Sigma-Aldrich Chemie GmbH (Germany). All other chemicals used in this study were analytical grade. Deionized and distillated water was used for all experiments.

\subsection{Patients and Biological Material}

The study population consisted 20 PD patientstreated with Madopar, 18 PD patients without administration. All of patients were in the age group of $59-78$ years old and were patients of the Neurological Clinic of University Hospital, Stara Zagora, Bulgaria. The PD diagnoses were made by taking a detailed history and studying the disease symptoms. For controls were used 20 age-matched healthy volunteers (Table 1).

No obvious differences were found in the severity of disease and the dose of antiparkinsonian drugs between female and male cases. To eliminate other factors that might affect the oxidative stress parameters, we have chosen PD patients and healthy volunteers all were neither smokers nor suffering from acute or chronic diseases. Informed consent was obtained from all participants in the study according to the ethical guidelines of the Helsinki Declaration.

\subsection{Biochemical Investigation}

Fasting samples of venous blood were collected in the morning in tubes with anticoagulant and was used to

Table 1. Clinical characteristics of PD patients control subjects.

\begin{tabular}{|c|c|c|c|c|c|}
\hline Group & Therapy & Male/Female & Age & Disease Duration & $\begin{array}{l}\text { Therapy } \\
\text { Duration }\end{array}$ \\
\hline $\begin{array}{c}\text { Parkinson } \\
\text { Disease }\end{array}$ & $\begin{array}{c}\text { Therapy } \\
\text {-Madopar } 250 \mathrm{mg} \\
1+1+1+1 / 2\end{array}$ & $\begin{array}{c}\text { Men - } 8 \\
\text { women - } 10\end{array}$ & $55-70$ & from 6 to 8 years & from 2 to 4 years \\
\hline $\begin{array}{c}\text { Parkinson } \\
\text { Disease }\end{array}$ & Without therapy & $\begin{array}{c}\text { men - } 10 \\
\text { women - } 10\end{array}$ & $55-70$ & from 1 to 2 years & without therapy \\
\hline $\begin{array}{c}\text { Healthy } \\
\text { Volunteers }\end{array}$ & Controls & $\begin{array}{c}\text { men - } 8 \\
\text { women - } 12\end{array}$ & $50-65$ & healthy volunteers & healthy volunteers \\
\hline
\end{tabular}


determinated the product of lipid peroxidation. For PCC and 8-OHdG was collected whole blood in a covered test tube (without anticoagulant). All samples from each subject were split and run in triplicate.

\subsection{Determination of the Lipid Peroxidation Products}

Total amount of lipid peroxidation products in the plasma of healthy volunteers and patients was estimated using the thiobarbituric acid (TBA) method modified by Gadjeva et al., and measurement of MDA at $532 \mathrm{~nm}$ [13]. Results were expressed in $\mu \mathrm{mol} / \mathrm{l}$.

\subsection{Haemoglobin Concentrations}

Haemoglobin lysates concentrations were analyzed by cyanmethaemoglobin method [14].

\subsection{Measurement of Protein Carbonylcontent}

PCC was measured by using a commercial ELISA kit followed manufacturer's instructions.

\subsection{Measurement of 8-OHdG Quantity}

The quantitative measurement of 8-OHdG were carried out using commercial ELISA kit, followed manufacturer's instructions.

\subsection{Statistical Analysis}

Statistical analysis was carried out using Statistics 7 for Windows. The results were reported as means \pm SD (SE). Student's t-test was used to determine the statistical difference between groups. $\mathrm{P} \leq 0.001$ was considered statistically significant.

\section{Results and Discussion}

Lipids are the most easily oxidizable which makes them the most preferred object for the study of free radical injuries via lipid peroxidation. Literature data show that in the brain of PD patients the amount of products of lipid peroxidation (LPO) (measured as MDA) is increased and the concentration of polyunsaturated fatty acids decreased, which is considered as an indicator of increased LPO in the SN.

Sanyal et al. reported that PD patients levels of plasma MDA is significantly higher than in controls [15], which imply that increased LPO is a risk factor for the presence of oxidative stress. The plasma MDA, represented in Figure 1 was no statistically significant difference in the values in PD patients with Madopar treatment relative to control group (mean $2.46 \mu \mathrm{mol} / 1 \pm 0.1$ vs mean $2.39 \mu \mathrm{mol} / 1 \pm 0.04, \mathrm{p}<0.36$, t-test), but there is a statistically significant increase in MDA levels between PD patients without therapy compared to controls (mean $3.38 \mu \mathrm{mol} / 1 \pm 0.08$ vs mean $2.39 \mu \mathrm{mol} / 1 \pm 0.04, \mathrm{p}<0.00$, t-test). Statistically significantly decrease was measured between PD patients receiving Madopar compared to PD patients without treatment (mean $2.46 \mu \mathrm{mol} / 1 \pm$ 0.1 vs mean $3.38 \mu \mathrm{mol} / 1 \pm 0.08, \mathrm{p}<0.00$, t-test).

It is well known that lipid peroxidation of plasma and intracellular membranes leads to distortion of the overall cell metabolism, and has a cytotoxic effect. MDA can react with proteins and nucleic acids, and so impair certain physiological mechanisms in the human body. PD may serve as an excellent example to discuss the significance of oxidative processes as a central, but not an initiating event for the development of clinical disease. The concept that OS occurs in PD derives primarily from the realization of dopamine metabolism, by chemical or enzymatic means that can generate free radicals and other ROS via autoxidation and dopamine oxidation. Biochemical evidence of oxidative injury can be suggested through the detection of products of oxidation of lipids, proteins and nucleic acids, such as MDA, PCC and quantity of 8-OHdG [15] [16].

Therefore the results of our study indicate that oxidative stress increased in PD patients without therapy which is due to the increased levels of LPO and are in agreement with studies of Jenner \& Olanov, Sudha et al. and Barnham et al. [17]-[19]. MDA is able to impair several physiological mechanisms of the human body through its ability to react with molecules such as DNA and proteins [20]. Cell membrane lipids are the most common substrates for oxidative attack [21]. According to Barnham et al. [17], MDA increases in PD brains and whereas, increased TBARs observed in the plasma of untreated PD patients measured by Dexter et al. and Sanyal et al., 


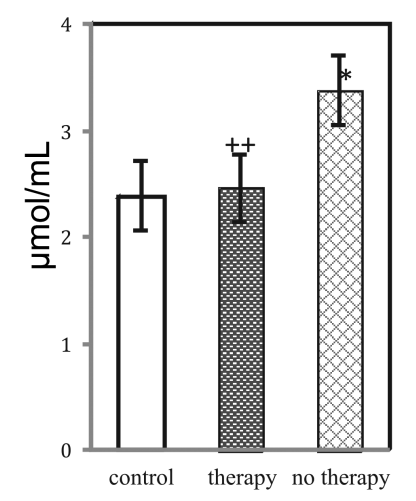

Figure 1. MDA plasma levels in controls, PD patients with therapy Madopar and PD patients without drug therapy. Results are presented as mean values \pm SE $\mathrm{p}<0.05 ;(*)$ - statistical significance relative to the controls; $(++)$ statistical significance compared to PD patients without drugtreatment.

comparing with controls, which is consistent with our results [15] [22].

The oxidative modification of proteins leads to increased recognition and degradation by proteases and loss of enzymatic activity [23]-[25]. The chemical reactions resulting from ROS attack upon proteins are complex, and generate radicals from amino acid residues, so electrons can be transferred between different amino acids. It has been shown that OS increased protein oxidation in various diseases [26] including PD. A lot of studies conducted in different areas of the brain in patients who died of Parkinson's disease, show presence of increased levels of oxidised proteins especially in SN [9] [27] [28]. One way to measure protein oxidation is to determine levels of PCC [29] [30]. The levels of PCC could be used to assess the oxidative protein damage [31] [32]. As it can be seen on Figure 2 the PCC in PD patients with drug administration were statistically higher compared to the controls (mean $7.72 \mathrm{nmol} / \mathrm{mg} \pm 0.3$, vs mean $1.25 \mathrm{nmol} / \mathrm{mg} \pm 0.2, \mathrm{p}=0.00$, t-test) and to PD patients without drug administration (mean $7.72 \mathrm{nmol} / \mathrm{mg} \pm 0.3$, vs mean $5.17 \mathrm{nmol} / \mathrm{mg} \pm 0.1, \mathrm{p}=0.00$, t-test). The same changes in PCC are demonstrated in studies on Beal [33]. Such increase in PCC may be a result of treatment with levodopa (the main ingredient of Madopar), which are accepted from all PD patients in the therapy group [9] [34]-[36], so levodopa can act as an in vitro pro oxidant and probably in vivo [37] [38].

In comparison between the group of PDpatients without therapy with controls also had a statistically significant increase (mean $5.17 \mathrm{nmol} / \mathrm{mg} \pm 0.1$, vs mean $1.25 \mathrm{nmol} / \mathrm{mg} \pm 0.2, \mathrm{p}=0.00$, t-test), which indicates that impacts of disease may also damaged the proteins and confirmed the role of oxidative stress in disease pathology.

There are significant data [39] [40] ascribe that the toxic accumulation of aggregated and misfolded proteins may cause loss of nigral neurons in PD [2] [17]. Furthermore, the products of oxidative protein damage can contribute to secondary damage to other biomolecules, for example, inactivation of DNA repair. When oxidized DNA is repaired, 8-OHdG is excreted in the blood and in urine, where it can be measured, and as such, it has emerged as a marker of oxidation. The $8-\mathrm{OHdG}$ is a product of DNA nucleoside oxidation and is generated by oxidation of guanine. Hence, $8-\mathrm{OHdG}$ can be viewed as a biochemical marker of injury induced $\cdot \mathrm{OH}$. Several studies have reported that $8-\mathrm{OHdG}$ levels in neuronal cells of the SNare higher in PD patients than in healthy controls [27]. Furthermore, in the cerebrospinal fluids, plasma and urine the levels of 8-OHdG in PD patients were found to be significantly higher than levels in controls.

Figure 3 represents the DNA damage, measured as amount 8-OHdG by ELISA method, in samples from PD patients with and without therapy. There is a statistically significant increase in the amount of 8-OHdG in PD patients treated with Madopar compared with controls (mean $18.5 \mathrm{ng} / \mathrm{ml} \pm 0.2 \mathrm{vs}$ mean $11.31 \mathrm{ng} / \mathrm{ml} \pm 0.1, \mathrm{p}<$ 0.00 , t-test), while in PD patients without therapy increases is insignificant compared to controls (mean 16.2 $\mathrm{ng} / \mathrm{ml} \pm 0.4 \mathrm{vs}$ mean $11.31 \mathrm{ng} / \mathrm{ml} \pm 0.1, \mathrm{p}<0.6$, t-test), and are in agreement with those reported by Sato et al., and Isobe et al., [41] [42]. Statistically significant increase was observed in the amount of 8-OHdG measured in PD patients with treatment compared to PD patients without drug administration (mean $18.5 \mathrm{ng} / \mathrm{ml} \pm 0.2 \mathrm{vs}$ mean $16.2 \mathrm{ng} / \mathrm{ml} \pm 0.4, \mathrm{p}<0.00)$. 


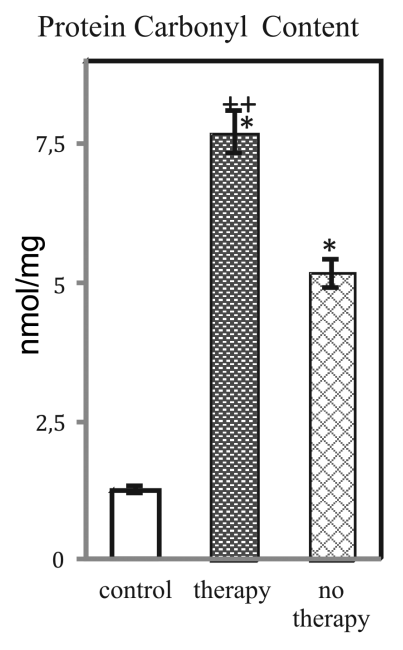

Figure 2. Protein Carbonyl Content (PCC) in PD patients with Madopar therapy, patients without therapy and controls; $\mathrm{p}<0.05$; $\left({ }^{*}\right)$ relative to controls, $(++)$ compared with PD patients without drug treatment.

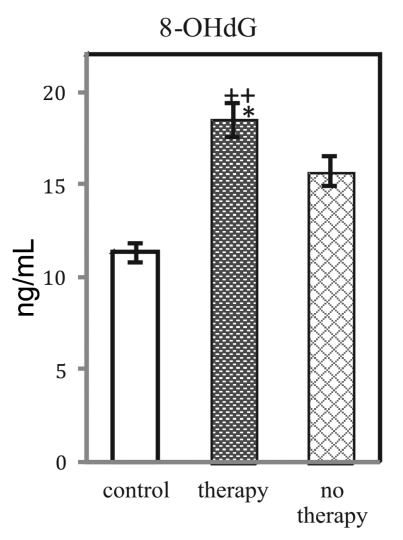

Figure 3. DNA damage, measured as $8-\mathrm{OHdG}(\mathrm{ng} / \mathrm{ml})$ in controls, PD patients with therapy Madopar and PD patients without drug therapy. $\mathrm{p}<0.05$; $\left(^{*}\right)$ - relative to the controls, $(++)$ - compared with PD patients without drug treatment.

The results suggested that in PD patients without drug therapy OS increased, this is demonstrated by elevated levels of the end products of oxidation of lipids (measured as MDA), proteins (PCC) and nucleic acids (8-OHdG). In the group of PD patients with drug therapy our results coincide with Stadman et al., Alam et al., Cornetta et al., Prigione et al., Floor et al., [6] [10] [26] [43] [44], who have reported elevated levels of PCC and significant increase of nucleic acid measured as 8-OHdG during L-dopa treatment compared to untreated PD patients and controls. After treatment with (Madopar) L-dopa oxidative stress progresses, as there is a statistically significant increase in the values of the PCC and 8-OHdG. However, some authors indicated on positive correlation between OS and L-dopa therapy [4] [17] [45], but there are also negative correlation between OS and L-dopa dosage in peripheral blood lymphocytes [6] [41] [42]. It can be assumed that DNA damage is due to the treatment with L-dopa, which can lead to the generation of $\mathrm{H}_{2} \mathrm{O}_{2}$ and consequently to $\cdot \mathrm{OH}$ formation through autoxidation and metabolism of monoamineoxidase. However, only $\mathrm{H}_{2} \mathrm{O}_{2}$ or only L-dopa does not lead to modification of DNA bases, whereas the combination of $\mathrm{H}_{2} \mathrm{O}_{2}$ with transition metal ions (iron and copper) produces a wide range of end-products of the DNA damage. According to Alam et al., and Kikuchi et al., it seems unlikely that the selective increase of 8-OHdG is due to L-dopa treatment [10] [11]. Anyway the data indicate increased oxidative activity in PD substantia nigra and are in conformity with the view that oxidative stress plays a major role in the loss of dopaminergic cells in PD patients. Our results confirm previous studies of 8-OHdG increased content in PD 
patients with L-dopa therapy. Probably, the changes are not only due to the increase of free radical damage, but also in the change of chemical nature of the guanine damage products.

There is a lot of evidence that PD brain is oxidatively damaged, which is observed within L-dopa therapy [9] [10] [46]-[49].

\section{Conclusion}

In view of these facts we can conclude that presented results from our study confirm the concept that oxidative stress is increased in PD patients by elevated plasma levels of MDA, PCC modified proteins and the amount of 8-OHdG. The long-term drug administration can cause further oxidative stress and imbalance between the production and elimination of ROS could contribute to the pathogenesis of PD and other neurodegenerative disorders. In conclusion, we believe that the Levodopa (Madopar) administration results in a greater degree of oxidative stress, than is induced by PD itself. Further studies are needed to clarify the effect of the combined therapy with antioxidants, which would have a protective effect on Madopar-induced oxidative toxicity

\section{Acknowledgements}

This work was supported by the scientific projects No 12/2012 and No 4/2013, Medical faculty, Trakia University. Authors thank to the European Social Fund, Structural Funds, and Operational Programme "Human Resources Development" for financial support in frame of Grant BG051PO001-3.3.06-0006.

\section{References}

[1] Nagal, A. and Singla R.K. (2012) Parkinson's Disease: Diagnosis, Therapeutics \& Management. Webmed Central Pharmaceutical Sciences, 3, Article ID: WMC003670.

[2] Halliwell, B. (1992) Reactive Oxygen Species and the Central Nervous System. Journal of Neurochemistry, 59, 16091623. http://dx.doi.org/10.1111/j.1471-4159.1992.tb10990.x

[3] Halliwell, B. and Chirico, S. (1993) Lipid Peroxidation: Its Mechanism, Measurement and Significance. The American Journal of Clinical Nutrition, 57, 715S-724S.

[4] Jolanta, D. and Wojciech, K. (2011) Oxidative DNA Damage and the Level of Biothiols, and L-Dopa Therapy in Parkinson's Disease. In: Rana, A.Q., Ed., Etiology and Pathophysiology of Parkinson's Disease, InTech, Chapter 16. http://dx.doi.org/10.5772/18594

[5] Nikolova, G. and Mancheva, V. (2013) Analysis of the Parameters of Oxidative Stress in Patients with Parkinson's Disease. Comparative Clinical Pathology, 22, 151-155. http://dx.doi.org/10.1007/s00580-012-1407-8

[6] Cornetta, T., Palma, S., Aprile, I., Padua, L., Tonali, P., Testa, A. and Cozzi, R. (2009) Levodopa Therapy Reduces DNA Damage in Peripheral Blood Cells of Patients with Parkinson's Disease. Cell Biology and Toxicology, 25, 321330. http://dx.doi.org/10.1007/s10565-008-9086-6

[7] Gilgun-Sherki, Y., Melamed, E. and Offen, D. (2001) Oxidative Stress Induced-Neurodegenerative Diseases: The Need for Antioxidants That Penetrate the Blood Brain Barrier. Neuropharmacology, 40, 959-975. http://dx.doi.org/10.1016/S0028-3908(01)00019-3

[8] Lotharius, J. and Brundin, P. (2002) Pathogenesis of Parkinson's Disease: Dopamine, Vesicles and $\alpha$-Synuclein. Nature Reviews Neuroscience, 3, 932-942. http://dx.doi.org/10.1038/nrn983

[9] Alam, Z.I., Daniel, S.E., Lees, A.J., Marsden, D.C., Jenner, P. and Halliwell, B. (1997) A Generalised Increase in Protein Carbonyls in the Brain in Parkinson's But Not Incidental Lewy Body. Journal of Neurochemistry, 69, 1326-1329. http://dx.doi.org/10.1046/j.1471-4159.1997.69031326.x

[10] Alam, Z.I., Jenner, A., Daniel, E., Lees, A.J., Cairns, N., Marsden, D., Jenner, P. and Halliwell, B. (1997) Oxidative DNA Damage in the Parkinsonian Brain: An Apparent Selective Increase in 8-Hydroxyguanine Levels in Substantia Nigra. Journal of Neurochemistry, 69, 1196-1203. http://dx.doi.org/10.1046/j.1471-4159.1997.69031196.x

[11] Kikuchi, A., Takeda, A., Onodera, H., Kimpara, T., Hisanaga, K., Sato, N., Nunomura, A., Castellani, R.J., Perry, G., Smith, M.A. and Itoyama, Y. (2002) Systemic Increase of Oxidative Nucleic Acid Damage in Parkinson's Disease and Multiple System Atrophy. Neurobiology of Disease, 9, 244-248. http://dx.doi.org/10.1006/nbdi.2002.0466

[12] Giammarioli, S., Filesi, C. and Sanzini, E. (1999) Oxidative Stress Markers: Specificity and Measurement Techniques. Annali-Istituto Superiore di Sanità, 35, 563-576.

[13] Gadjeva, V., Kuchukova, D. and Georgieva, R. (2005) Influence of Polychemotherapy on the Antioxidant Levels and Lipid Peroxidation in Patients with Lymphoproliferative Diseases. Comparative Clinical Pathology, 14, 13-18. 
http://dx.doi.org/10.1007/s00580-005-0556-4

[14] Mahoney, J.J., Vreman, H.J., Stevenson, D.K. and Van Vessel, A.L. (1993) Measurements of Carboxyhaemoglobin by Five Spectrophotometers (Cooximeters) in Comparison with Reference Methods. Clinical Chemistry, 39, 1693.

[15] Sanyal, J., Bandyopadhyay, S.K., Banerjee, T.K., Mukherjee, SC, Chakraborty, D.P., Ray, B.C. and Rao, V.R. (2009) Plasma Levels of Lipid Peroxides in Patients with Parkinson's Disease. Europ. European Review for Medical and Pharmacological Sciences, 13, 129-132.

[16] Gadjeva, V., Dimov, A. and Georgieva, N. (2008) Influence of Therapy on the Antioxidant Status in Patients with Melanoma. Journal of Clinical Pharmacy and Therapeutics, 33, 179-185. http://dx.doi.org/10.1111/j.1365-2710.2008.00909.x

[17] Barnham, K.J., Masters, C.L. and Bush, A.I. (2004) Neurodegenerative Diseases and Oxidative Stress. Nature Reviews Drug Discovery, 3, 205-214. http://dx.doi.org/10.1038/nrd1330

[18] Jenner, P. and Olanow, W. (1996) Oxidative Stress and the Pathogenesis of Parkinson's Disease. Neurology, 47, 161170. http://dx.doi.org/10.1212/WNL.47.6 Suppl 3.161S

[19] Sudha, K., Rao, A., Rao, S. and Rao, A. (2003) Free Radical Toxicity and Antioxidants in Parkinson's Disease. Neurology India, 51, 60.

[20] Rio, D.D., Stewart, A.J. and Pellegrini, N. (2005) A Review of Recent Studies on Malondialdehyde as Toxic Molecule and Biological Marker of Oxidative Stress. Nutrition, Metabolism \& Cardiovascular Diseases, 15, 316-328. http://dx.doi.org/10.1016/j.numecd.2005.05.003

[21] de Zwart, L.L., Meerman, J.H.N., Commandeur, J.N.M. and Vermeulen, N.P.E. (1999) Biomarkers of Free Radical Damage. Applications in Experimental Animals and in Human. Free Radical Biology and Medicine, 26, 202-226. http://dx.doi.org/10.1016/S0891-5849(98)00196-8

[22] Dexter, D.T., Carter, C., Agid, F., Lees, A.J., Jenner, P. and Marsden, C.D. (1986) Lipid Peroxidation as a Cause of Nigral Cell Death in Parkinson Disease. The Lancet, 2, 639-640. http://dx.doi.org/10.1016/S0140-6736(86)92471-2

[23] Davies K.J. and Delsignore M.E. (1987) Protein Damage and Degradation by Oxygen Radicals. III. Modification of Secondary and Tertiary Structure. Journal of Biological Chemistry, 262, 9908-9913.

[24] Hawkins, C.L. and Morgan, P.E. (2009) Quantification of Protein Modification by Oxidants. Free Radical Biology and Medicine, 46, 965-988. http://dx.doi.org/10.1016/j.freeradbiomed.2009.01.007

[25] Stadtman, E.R. (1992) Protein Oxidation and Aging. Science, 257, 1220-1224. http://dx.doi.org/10.1126/science.1355616

[26] Yoritaka, A., Hattori, N., Uchida, K., Tanaka, M., Stadtman, E.R. and Mizuno, Y. (1996) Immunohistochemical Detection of 4-Hydroxynonenal Protein Adducts in Parkinson Disease. Proceedings of the National Academy of Sciences of the United States of America, 93, 2696-2701. http://dx.doi.org/10.1073/pnas.93.7.2696

[27] Youdim, M.B., Drigues, N. and Mandelm S. (2001) Oxidative Stress Indices in Parkinson's Disease. In: Mouradian, M.M., Ed., Parkinson's disease, Humana Press, New York, 137-153. http://dx.doi.org/10.1385/1-59259-142-6:137

[28] Dalle-Donne, I., Giustarini, D., Colombo, R., Rossi, R. and Milzani, A. (2003) Protein Carbonylation in Human Diseases. Trends in Molecular Medicine, 9, 169-176. http://dx.doi.org/10.1016/S1471-4914(03)00031-5

[29] Davies, K.J. and Goldberg, A.L. (1987) Proteins Damaged by Oxygen Radicals Are Rapidly Degraded in Extracts of Red Blood Cells. Journal of Biological Chemistry, 262, 8227-8234.

[30] Nyström, T. (2005) Role of Oxidative Carbonylation in Protein Quality Control and Senescence. The EMBO Journal, 24, 1311-1317. http://dx.doi.org/10.1038/sj.emboj.7600599

[31] Levine, R.L. (2002) Carbonyl Modified Proteins in Cellular Regulation, Aging, and Disease. Free Radical Biology and Medicine, 32, 790-796. http://dx.doi.org/10.1016/S0891-5849(02)00765-7

[32] Rivett, A.J. and Levine, R.L. (1990) Metal-Catalyzed Oxidation of Escherichia coli Glutamine Synthetase: Correlation of Structural and Functional Changes. Archives of Biochemistry and Biophysics, 278, 26-34. http://dx.doi.org/10.1016/0003-9861(90)90226-O

[33] Beal, M.F. (2002) Oxidatively Modified Proteins in Aging and Disease. Free Radical Biology and Medicine, 32, 797803. http://dx.doi.org/10.1016/S0891-5849(02)00780-3

[34] Deans, S.G., Noble, R.C., Penzes L. and Imre, S.G. (1993) Promotional Effects of Plant Volatile Oils on the Polyunsaturated Fatty Acid Status during Aging. Age, 16, 71-74. http://dx.doi.org/10.1007/BF02435040

[35] Lyras, L., Evans, P.J., Shaw, P.J., Ince, P.G. and Halliwell, B. (1996) An Assessment of Oxidative Damage to Proteins, Lipids, and DNA in Brain from Patients with Alzheimer's Disease. Free Radical Research, 24, 397-406.

[36] Smith, J.F., Hardcastle, J.D., Denton, G., Alderson, D., Grase, R.H., Mansi, J.L., Yosef, H.M., Nordle, O., Lauri, H. and Wahlby, S. (1995) Two Phase III Trials of Tauromustine (TCNU) in Advanced Colorectal Cancer. Annals of On- 
cology, 6, 948-949.

[37] Fahn, S. and the Parkinson Study Group (2005) Does Levodopa Slow or Hasten the Rate of Progression of Parkinson's Disease? Journal of Neurology, 252, IV/37-IV/42.

[38] Spencer, J.P.E., Jenner, A., Butler, J., Aruoma, I., Dexter, D.T., Jenner, P. and Halliwell, B. (1996) Oxidative DNADamage in Human Respiratory-Tract Epithelial-Cells-Time-Course in Relation to DNA Strand Breakage. Free Radical Research, 24, 95-105.

[39] Quintero, J.E., Wang, X. and Zhang, Z. (2011) Developing an MRI-Based Biomarker for Early Diagnosis of Parkinson's Disease. InTech. http://dx.doi.org/10.5772/18458

[40] Melo, A., Monteiro, L., Lima, R.M.F., de Oliveira, D.M., de Cerqueira, M.D. and El-Bachá, R.S. (2011) Oxidative Stress in Neurodegenerative Diseases: Mechanisms and Therapeutic Perspectives. Oxidative Medicine and Cellular Longevity, 2011, Article ID: 467180. http://dx.doi.org/10.1155/2011/467180

[41] Isobe, C., Abe, T. and Terayama, Y. (2010) Levels of Reduced and Oxidized CoenzymeQ-10 and 8-hydroxy-2-deoxyguanosine in the Cerebrospinal Fluid of Patients with Living Parkinson's Disease Demonstrate That Mitochondrial Oxidative Damage and/or Oxidative DNA Damage Contributes to the Neurodegenerative Process. Neuroscience Letters, 469, 159-163. http://dx.doi.org/10.1016/j.neulet.2009.11.065

[42] Floor, E. and Wetzel, M.G. (1998) Increased Protein Oxidation in Human Substantia Nigra Pars Compacta in Comparison with Basal Ganglia and Prefrontal Cortex Measured with an Improved Dinitrophenylhydrazine Assay. Journal of Neurochemistry, 70, 268-275. http://dx.doi.org/10.1046/j.1471-4159.1998.70010268.x

[43] Prigione, A., Begni, B., Galbussera, A., Beretta, S., Brighina, L., Garofalo, R., Andreoni, S., Piolti, R. and Ferrarese, C. (2006) Oxidative Stress in Peripheral Blood Mononuclear Cells from Patients with Parkinson's Disease: Negative Correlation with Levodopa Dosage. Neurobiology of Disease, 23, 36-43. http://dx.doi.org/10.1016/j.nbd.2006.01.013

[44] Sato, S., Mizuno, Y. and Hattori, U. (2005) Urinary 8-Hydroxydeoxyguanosine Levels as a Biomarker for Progression of Parkinson Disease. Neurolog, 64, 1081-1083. http://dx.doi.org/10.1212/01.WNL.0000154597.24838.6B

[45] Florczak, J., Dorszewska, J. and Kozubski, W. (2008) Influence of L-Dopa Treatment Duration on the Level of Oxidative Damage to DNA and Thiol Compound Concentration in Patients with Parkinson's Disease. Neurologia i Neurochirurgia Polska, 42, S36-S44.

[46] Parkinson Study Group (2004) Pramipexole vs Levodopa as Initialtreatment for Parkinson Disease-A 4-Year Randomized Controlled Trial. Archives of Neurology, 61, 1044-1053.

[47] Halliwell, B. (2001) Role of Free Radicals in the Neurodegenerative Diseases: Therapeutic Implications for Antioxidant Treatment. Drugs \& Aging, 18, 685-716. http://dx.doi.org/10.2165/00002512-200118090-00004

[48] Halliwell, B. (2006) Oxidative Stress and Neurodegeneration: Where Are We Now? Journal of Neurochemistry, 97, 1634-1658. http://dx.doi.org/10.1111/j.1471-4159.2006.03907.x

[49] Lan, J., Henshall, D.C., Simon, R.P. and Chen, J. (2000) Formation of the Base Modification 8-Hydroxyl-2'-Deoxyguanosine and DNA Fragmentation Following Seizures Induced by Systemic Kainic Acid in the Rat. Journal of Neurochemistry, 74, 302-309. http://dx.doi.org/10.1046/j.1471-4159.2000.0740302.x 